\title{
CD226 gene polymorphisms are associated with non-small-cell lung cancer in the Chinese Han population
}

This article was published in the following Dove Press journal:

Therapeutics and Clinical Risk Management

24 August 2015

Number of times this article has been viewed

\author{
Zhi-Xin Qiu ${ }^{1, *}$ \\ Ying Peng 2 ,* \\ Wei-Min $\mathrm{Li}^{1}$ \\ 'Department of Respiratory Medicine, \\ ${ }^{2}$ Department of Cardiology, West \\ China Hospital, Sichuan University, \\ Chengdu, People's Republic of China \\ *These authors contributed equally \\ to this work
}

Background: The immunoglobulin-like glycoprotein CD226 (DNAX accessory molecule-1) represents receptor-activating cytotoxic T lymphocyte and natural killer cells taking part in tumor surveillance, the pathogenesis of inflammation, and autoimmune disorders. The aim of the present study is to analyze the association between polymorphisms rs763361 and rs727088 in the CD226 gene and their impact on the pathogenesis of non-small-cell lung cancer (NSCLC).

Materials and methods: Polymerase chain reaction (PCR)-restriction fragment length polymorphisms (RFLP) were used to genotype the single nucleotide polymorphisms (SNPs) rs763361 and rs727088 of the CD226 gene in 302 NSCLC patients and 389 ethnicity matched healthy controls.

Results: The frequencies of the T allele and TT genotype of rs763361 (T allele odds ratio [OR] $1.42,95 \%$ confidence interval [CI] 1.14-1.77; TT genotype OR 2.73, 95\% CI 1.70-4.39), as well as the G allele and GG genotype of rs 727088 (G allele OR 1.89, 95\% CI 1.50-2.39; GG genotype OR 4.62, 95\% CI 2.31-9.20) in the NSCLC patients were significantly higher than that of normal controls, indicating that both of these two SNPs as risk factors were associated with NSCLC $(P<0.05)$. Results of stratified analysis revealed that the polymorphism of rs 727088 was associated with lymph node invasion and clinical stage cancer $(P<0.05)$. However, there was no association between SNP rs763361 and clinical characteristics.

Conclusion: Our results demonstrated that CD226 gene polymorphisms (T allele of rs763361 and $\mathrm{G}$ allele of rs727088) as risk factors were associated with NSCLC.

Keywords: CD226, NSCLC, polymorphism, DNAX

\section{Introduction}

Non-small-cell lung cancer (NSCLC) accounts for $80 \%$ of all lung cancers and is a leading cause of cancer mortality worldwide. ${ }^{1,2}$ Tobacco smoking is the most wellestablished risk factor for lung cancer. Another important risk factor is environmental exposure to chemical carcinogens or occupational carcinogens. Moreover, genetic factors also play a crucial role in the pathogenesis of NSCLC. ${ }^{1,2}$

CD226, also known as DNAX accessory molecule 1 (DNAX1) or platelet and $\mathrm{T}$ cell antigen 1, is a transmembrane glycoprotein belonging to the immunoglobulin superfamily and contains two IG-like domains in its extracellular portion. It is highly conserved among humans, gibbons, monkeys, and mice, and its gene has been mapped to human chromosome $18 .^{3-6}$ In humans, CD226 is expressed on the majority of natural killer (NK) cells, T cells, and monocytes, and on a small subset of B cells. ${ }^{5}$

Recently, rs763361 (C/T polymorphism), the non-synonymous (Gly307Ser) coding variant that is located at $18 \mathrm{q} 22.3$ in the $C D 226$ gene, was first correlated to type 1
Department of Respiratory Medicine, West China Hospital, Sichuan University, No 37, Guoxuexiang Street, Chengdu, 6I004I, People's Republic of China Tel +862885423998

Email weimi003@yahoo.com 
diabetes susceptibility, and has been shown to be associated with multiple autoimmune diseases and systemic sclerosis (SSc). ${ }^{7,8}$ In addition, the rs763361 glycine-to-serine substitution could interfere in the phosphorylation of CD226 at 322Tyr and 329Ser residues, and may modulate the downstream signaling pathway via these posttranslational modifications. ${ }^{9,10}$ Furthermore, a three-variant haplotype in CD226 gene (rs763361-rs34794968-rs727088) was found to be associated with systemic lupus erythematosus in recent research, and the authors suggested that rs727088 may be the single nucleotide polymorphism (SNP) with a functional influence on CD226 transcription levels. ${ }^{11}$ Another study performed on SSc subjects proposed that genetic variants, including CD226 rs763361, rs727088, and rs3479968 did not influence SSc susceptibility, but that a CD226 three-variant haplotype did cause genetic predisposition to SSc-related pulmonary fibrosis. ${ }^{12}$ Additionally, two earlier studies reported that CD226 polymorphism was associated with susceptibility to gastric cancer and cervical squamous cell carcinoma. ${ }^{13,14}$

Considering the important role of CD226 and its ligands in diseases, it is necessary to investigate whether CD226 is a candidate susceptible gene to cancers. However, to our knowledge, there is no report about the relationship between CD226 polymorphisms and lung cancer. Therefore, in the present study, we attempted to clarify the association between CD226 gene polymorphisms (rs763361 and rs727088) and NSCLC, and we have found that CD226 gene polymorphisms (rs763361 and rs727088) are associated with NSCLC.

\section{Materials and methods Study subjects}

A total of 302 unrelated Chinese patients with NSCLC were recruited from the West China First University Hospital, Sichuan University from January 2010 to January 2012. The patients (age, mean \pm standard deviation [SD], 60.29 \pm 10.11 years; male/female ratio, 216/86) consisted of 138 adenocarcinomas, 138 squamous cell carcinomas, and 26 other types of cancer, including adenosquamous carcinomas and largecell carcinomas. All patients were adjuvant therapy-free. The control group consisted of 389 healthy subjects (age, mean \pm $\mathrm{SD}, 61.71 \pm 12.14$ years; male/female ratio, 278/111) from a routine health survey in the same hospital. Control subjects were genetically unrelated and without any personal or family history of cancer or other serious disease. The diagnosis of NSCLC was confirmed by histological examination of tissues from biopsy. Data on stages were presented according to the International Union Against Cancer's tumor node metastasis system, and differentiation and histological type were measured according to the World Health Organization classification for NSCLC. ${ }^{15}$ The study design and procedure were approved by the institutional review board of West China Hospital, and all patients completed a written informed consent before enrollment.

\section{Determination of genotypes}

Genomic DNA of each subject was extracted from $200 \mu$ L ethylenediaminetetraacetic acid (EDTA)-anticoagulated peripheral blood samples with a DNA isolation kit from BioTeke Corporation (Peking, People's Republic of China), and the procedure was performed according to the manufacturer's instructions. The primers were established with the primer-introduced restriction analysis (PIRA) polymerase chain reaction (PCR) designer (http://primer1.soton.ac.uk/primer2.html). The rs763361 primers, which were used for amplification, were 5'-TTTGGTCTGCGAGAGAAGGT-3' and 5'-TGCCTGCATTTATGAGAGGT-3', and the primers used for amplification of the rs727088 were 5'-TCCCTCCCAAATTTCTACCC-3' and 5'-CCATCCCAGGTCTAGCCTTA-3'.

The PCR reactions were performed in a total volume of $25 \mu \mathrm{L}$, composed of $2.5 \mu \mathrm{L} 10 \times$ PCR buffer, $1.5 \mathrm{mmol} / \mathrm{L}$ of $\mathrm{MgCl}_{2}, 0.15 \mathrm{mmol} / \mathrm{L}$ of deoxyribonucleotide triphosphates, $0.5 \mu \mathrm{mol} / \mathrm{L}$ of each primer, $100 \mathrm{ng}$ of genomic DNA, and $1 \mathrm{U}$ of Taq DNA polymerase. The PCR conditions for both SNPs were $94^{\circ} \mathrm{C}$ for 4 minutes, followed by 32 cycles of 30 seconds at $94^{\circ} \mathrm{C}, 30$ seconds at $62^{\circ} \mathrm{C}$, and 30 seconds at $72^{\circ} \mathrm{C}$, with a final elongation at $72^{\circ} \mathrm{C}$ for 10 minutes. PCR products were digested overnight with specific restriction enzymes ( $M s p$ I for rs763361 and Bcc I for rs727088), were then separated with a $6 \%$ polyacrylamide gel, and were stained with $1.5 \mathrm{~g} / \mathrm{L}$ of argent nitrate. For the rs 763361 polymorphism, allele $\mathrm{C}$ was divided into two fragments of $79 \mathrm{bp}$ and $126 \mathrm{bp}$; allele T was uncuttable, and the fragment was $205 \mathrm{bp}$; for the rs 727088 polymorphism, allele A was cuttable, yielding two fragments of $31 \mathrm{bp}$ and 208 bp; allele $\mathrm{G}$ was uncuttable, and the fragment was 239 bp. The genotypes were confirmed by the DNA sequencing analysis (BigDye ${ }^{\circledR}$ Terminator v3.1 Cycle Sequencing Kit; Thermo Fisher Scientific, Waltham, MA, USA). Approximately 20\% of the samples were randomly selected to perform the repeated assays, and the results were $100 \%$ concordant.

\section{Statistical analysis}

Genotype and allele frequencies of the two SNPs were calculated by directed counting. The chi-square test was used to compare the genotype and allele frequencies between two groups and to evaluate the Hardy-Weinberg equilibrium. Odds ratios (OR) and respective 95\% confidence intervals (95\% CIs) 
were reported to evaluate the effects of any difference between alleles and genotypes. Data analyses and summarizations were conducted using SPSS 17.0 for Windows (SPSS Inc, Chicago, IL, USA). Values of $P<0.05$ (2-sided) were considered to be statistically significant. The study power was calculated by using the Quanto 1.1.1 program (http://hydra.usc.edu/gxe).

\section{Results}

\section{Comparison of CD226 gene polymorphism between patients and controls}

The two CD226 SNPs were successfully genotyped in 302 NSCLC patients and 389 control subjects. The genotype distributions for SNP rs763361 and SNP rs727088 were in Hardy-Weinberg equilibrium $(P \geq 0.05)$ in both patients and controls. Three genotypes of both SNPs were identified, and the genotypes were confirmed by DNA sequencing analysis. Allele and genotype frequencies of these two SNPs were calculated and are summarized in Table 1. As shown in Table 1, significantly increased NSCLC risk was found to be associated with the T allele of SNP rs763361 $(P=0.001$; $\mathrm{OR}=1.42 ; 95 \% \mathrm{CI}=1.14-1.77)$, and with the $\mathrm{G}$ allele of SNP rs727088 $(P<0.001 ;$ OR $=1.89 ; 95 \% \mathrm{CI}=1.50-2.39)$.

\section{Association between CD226 polymorphisms and clinicopathologic characteristics of NSCLC patients}

Results of stratified analyses by clinicopathological features including sex, age, histological classification, tumor size, lymph node invasion, metastasis, and clinical stage for the two SNPs are presented in Tables 2 and 3. The rs763361 locus did not show any differences among stratified patient groups, whereas the frequencies of allele and genotype of the rs727088 locus were significantly different between patient groups with different stages of lymph node invasion ( $P=0.024$ and $P=0.042$, respectively, for allele and genotype) and clinical stage $(P=0.033)$. A significantly higher frequency of allele $\mathrm{G}$ was observed in patients with lymph node invasion at the N2 stage, and logistic-regression analysis revealed that allele $\mathrm{G}$ was associated with lymph node invasion (OR $=1.784$; 95\% CI =1.077-2.954).

The study power has been performed with the Quanto 1.1.1 program. Under a dominant genetic model, at the 0.05 level of significance with the two-sided test for the two polymorphisms, our current study had $94.99 \%$ and $96.80 \%$ power, respectively, for the rs763361 and the rs727088 polymorphisms to detect an effect with a relative risk of 1.8 in the group of NSCLC patients and in the group of healthy controls.

\section{Discussion}

Our present study provided the first evidence that both the $\mathrm{T} / \mathrm{C}$ of rs 763361 and the G/A of rs727088 were associated with NSCLC. The allele T of rs763361 and the allele G of rs727088 were remarkably correlated with NSCLC risk, indicating that CD226 may be used as a risk candidate biomarker for NSCLC susceptibility.

As an adhesion molecule and as a triggering receptor in NK and cytotoxic T lymphocyte (CTL) cells, ${ }^{5}$ CD226 is important for NK cell-mediated recognition of several human tumors, including myeloma, neuroblastoma, and Ewing's sarcoma. ${ }^{16-19}$ Adhesion molecules act directly as signaling molecules, initiating intracellular pathways that trigger activation and adhesiveness of CTL cells. They also

Table I Genotype and allele distribution of two single-nucleotide polymorphism loci in patients with non-small-cell lung cancer and normal controls

\begin{tabular}{|c|c|c|c|c|}
\hline SNP genotype/allele & $\begin{array}{l}\text { Patients } \\
n=302 \text { (\%) }\end{array}$ & $\begin{array}{l}\text { Controls } \\
n=389 \text { (\%) }\end{array}$ & $P$-value & OR (95\% Cl) \\
\hline \multicolumn{5}{|l|}{ rs76336I genotype } \\
\hline $\mathrm{CC}$ & $84(27.8)$ & $|5|(38.8)$ & Ref & Ref \\
\hline $\mathrm{CT}$ & $166(55.0)$ & $194(49.9)$ & $0.012^{\mathrm{a}}$ & $1.98(1.42-2.75)$ \\
\hline TT & $52(17.2)$ & $44(\mathrm{II} .3)$ & $<0.00 \mathrm{I}^{\mathrm{a}}$ & $2.73(1.70-4.39)$ \\
\hline \multicolumn{5}{|l|}{ Allele } \\
\hline C & $334(55.3)$ & $496(63.8)$ & $0.00 I^{\mathrm{a}}$ & $\mathrm{I} .42(\mathrm{I} .14-\mathrm{I} .77)$ \\
\hline $\mathrm{T}$ & $270(44.7)$ & $282(36.2)$ & & \\
\hline \multicolumn{5}{|l|}{ rs727088 genotype } \\
\hline AA & $109(36.1)$ & $218(56.0)$ & Ref & Ref \\
\hline AG & $163(54.0)$ & $158(40.6)$ & $<0.00 \mathrm{I}^{\mathrm{a}}$ & $2.06(1.50-2.83)$ \\
\hline GG & $30(9.9)$ & $13(3.3)$ & $<0.00 \mathrm{I}^{\mathrm{a}}$ & $4.62(2.31-9.20)$ \\
\hline \multicolumn{5}{|l|}{ Allele } \\
\hline$A$ & $38 I(63.1)$ & $594(76.3)$ & $<0.00 \mathrm{I}^{\mathrm{a}}$ & $1.89(1.50-2.39)$ \\
\hline G & $223(36.9)$ & $184(23.7)$ & & \\
\hline
\end{tabular}

Notes: aStatistically significant.

Abbreviations: OR, odds ratio; $\mathrm{Cl}$, confidence interval; SNP, single-nucleotide polymorphism; n, number of patients or controls; Ref, reference. 
Table 2 Association between clinical characteristics of patients with non-small-cell lung cancer and polymorphism of locus rs76336I

\begin{tabular}{|c|c|c|c|c|c|c|c|c|c|}
\hline \multirow[t]{2}{*}{ Characteristics } & \multirow{2}{*}{$\begin{array}{l}\text { Patients, } \\
\text { n }\end{array}$} & \multicolumn{3}{|c|}{ Genotype, n (\%) } & \multirow[t]{2}{*}{$P$-value } & \multicolumn{2}{|c|}{ Allele no (\%) } & \multirow[t]{2}{*}{$P$-value } & \multirow[t]{2}{*}{ OR (95\% Cl) } \\
\hline & & CC & CT & TT & & C & $\mathbf{T}$ & & \\
\hline \multicolumn{10}{|l|}{ Sex } \\
\hline Female & 86 & $26(30.2)$ & $51(59.3)$ & $9(10.5)$ & 0.161 & $103(59.5)$ & $69(40.1)$ & 0.155 & $1.30(0.91-1.86)$ \\
\hline Male & 216 & $57(26.4)$ & $115(53.2)$ & $42(19.4)$ & & $229(53.5)$ & $199(46.5)$ & & \\
\hline \multicolumn{10}{|l|}{ Age } \\
\hline$\leq 60$ years & 171 & $47(27.5)$ & $95(55.6)$ & $29(16.9)$ & 0.830 & $189(55.3)$ & $153(44.7)$ & 0.984 & $0.99(0.72-1.38)$ \\
\hline$>60$ years & $13 \mid$ & $37(28.2)$ & 7I (54.2) & $23(17.6)$ & & $145(55.3)$ & II (44.7) & & \\
\hline \multicolumn{10}{|l|}{ Histological type } \\
\hline $\mathrm{ADC}$ & 138 & $44(31.9)$ & $75(54.3)$ & $19(13.8)$ & & $163(59.1)$ & $113(40.9)$ & & \\
\hline SCC & 138 & $33(23.9)$ & $77(55.8)$ & $28(20.3)$ & 0.190 & $143(51.8)$ & $133(48.2)$ & 0.087 & $1.34(0.96-1.88)$ \\
\hline Others & 26 & 7 (26.9) & $14(53.8)$ & $5(19.2)$ & 0.733 & $28(53.8)$ & $24(46.2)$ & 0.485 & $1.24(0.68-2.24)$ \\
\hline \multicolumn{10}{|l|}{ Differentiation } \\
\hline Poor & 204 & 59 (28.9) & III (54.4) & $34(16.7)$ & 0.809 & $229(56.1)$ & $179(43.9)$ & 0.554 & I.II (0.79-I.56) \\
\hline Moderate-well & 98 & $25(25.5)$ & $55(56.1)$ & $18(18.4)$ & & $105(53.6)$ & $91(46.4)$ & & \\
\hline \multicolumn{10}{|l|}{ Tumor size } \\
\hline TI & 34 & II (32.4) & $17(50.0)$ & $6(17.6)$ & & $39(57.4)$ & $29(42.6)$ & & \\
\hline $\mathrm{T} 2$ & 192 & $53(27.6)$ & $106(55.2)$ & $33(17.2)$ & 0.828 & $212(55.2)$ & I $72(44.8)$ & 0.743 & $1.09(0.65-1.84)$ \\
\hline T3 & 51 & $15(29.4)$ & $27(52.9)$ & $9(17.6)$ & 0.955 & $57(55.9)$ & $45(44.1)$ & 0.850 & $1.60(0.57-1.97)$ \\
\hline $\mathrm{T} 4$ & 25 & $5(20.0)$ & $16(64.0)$ & $4(16.0)$ & 0.512 & $26(52.0)$ & $24(48.0)$ & 0.563 & $1.24(0.58-2.59)$ \\
\hline \multicolumn{10}{|l|}{ Lymph node } \\
\hline No & 156 & $43(27.6)$ & $83(53.2)$ & $30(19.2)$ & & $170(54.1)$ & I44 (45.7) & & \\
\hline NI & 107 & $36(33.6)$ & $56(52.3)$ & I5 (I4.0) & 0.407 & I 28 (59.8) & $86(40.2)$ & 0.197 & $0.79(0.56-1.13)$ \\
\hline N2 & 38 & $5(13.2)$ & $26(68.4)$ & 7 (18.4) & 0.147 & $36(47.4)$ & $40(52.6)$ & 0.289 & $1.31(0.79-2.17)$ \\
\hline \multicolumn{10}{|l|}{ Metastasis } \\
\hline Mo & 285 & $78(27.4)$ & I 57 (55.I) & $50(17.5)$ & 0.709 & $313(54.9)$ & $257(45.1)$ & 0.435 & $0.75(0.37-1.54)$ \\
\hline MI & 17 & $6(35.3)$ & $9(52.9)$ & $2(11.8)$ & & $21(6 \mid .8)$ & $13(38.2)$ & & \\
\hline \multicolumn{10}{|l|}{ Clinical stage } \\
\hline$I+I I$ & 223 & $67(30.0)$ & $116(52.0)$ & $40(17.9)$ & 0.209 & $250(56.1)$ & $196(43.9)$ & 0.577 & $0.89(0.62-1.28)$ \\
\hline$I I I+I V$ & 79 & $17(2 \mid .5)$ & $50(63.3)$ & $12(15.2)$ & & $84(53.2)$ & $74(46.8)$ & & \\
\hline
\end{tabular}

Abbreviations: ADC, adenocarcinoma; SCC, squamous cell carcinoma; OR, odds ratio; $\mathrm{Cl}$, confidence interval.

act as accessory molecules, sustaining cellular contacts that are necessary for the $\mathrm{NK}$ cell receptors and $\mathrm{T}$ cell receptors to engage their cognate ligands and to deliver intracellular signals. $^{7}$

NK cells display cytolytic activity against virus-infected cells and a wide variety of tumors of different histotypes. ${ }^{20}$ A role for NK cells in therapeutic intervention is becoming more apparent, such as in cases of melanoma, acute myeloid leukemia, and multiple myeloma. ${ }^{20-22}$ Emerging evidence suggests that CD226 plays an important role in T celland NK cell-mediated immunity to a variety of tumors expressing CD226 ligands. ${ }^{16,17,23-25}$ Many tumor cell lines of epithelial tissue origin express CD155 and/or CD112, which, as the main ligands for CD226, are lysed in vitro by NK cells and CTL cell lines in a CD226-dependent manner. ${ }^{5}$ The expression of CD155 and/or CD112 has also been detected in tumor samples from patients with metastatic neuroblastoma, some of which were shown to be susceptible to CD226-mediated lysis by activation of NK cells. ${ }^{17,26}$ In some vitro studies, it has been shown that CD226 triggers NK cell-mediated killing of a range of tumor cells expressing CD155 and CD112. ${ }^{16,17,24,27,28}$ NKT cells, ${ }^{\gamma \delta} \mathrm{T}$ cells, and CD4 $\mathrm{T}$ cells express CD226 when activated. ${ }^{18,29-31}$ CD226 binds to CD155 and to CD112, both of which have been found to be upregulated on tumors. CD155 is widely expressed on normal cells and is overexpressed on many tumor types. ${ }^{16,17,23,27,29-32}$ Moreover, some tumors overexpress CD155 and release it as a soluble molecule, ${ }^{33}$ possibly to block CD226 and to prevent recognition of tumor cells. ${ }^{20}$ One study demonstrated that the CD226-CD155 interaction is crucial for recognition, and through resting allogeneic NK cells, it can kill freshly isolated human ovarian carcinoma cells. ${ }^{23}$ Hence, these results may provide inspiration for the design of future protocols of adoptive NK cell- and antibody-based immunotherapies for ovarian carcinoma and possibly for other human tumors. ${ }^{23,34}$ Furthermore, the generation of autoreactive $\mathrm{T}$ cells may be regulated by CD226-CD155 interactions, emphasizing the importance of CD226 in the immune response. ${ }^{35}$

The importance of CD226 in tumor immunity on both NK cells and T cells has been shown in vivo. ${ }^{24}$ In murine models, two independent research groups have reported an increased risk of tumor development in mice lacking either the CD226 or NKG2G receptor. ${ }^{36,37}$ Compared with wide-type mice, CD226-deficient mice developed significantly more CD226 ligand-expressing fibrosarcoma and papilloma tumors in 
Table 3 Association between clinical characteristics of patients with non-small-cell lung cancer and polymorphism of locus rs727088

\begin{tabular}{|c|c|c|c|c|c|c|c|c|c|}
\hline \multirow[t]{2}{*}{ Characteristics } & \multirow{2}{*}{$\begin{array}{l}\text { Patients, } \\
\text { n }\end{array}$} & \multicolumn{3}{|c|}{ Genotype n (\%) } & \multirow[t]{2}{*}{$P$-value } & \multicolumn{2}{|c|}{ Allele n (\%) } & \multirow[t]{2}{*}{$P$-value } & \multirow[t]{2}{*}{ OR (95\% Cl) } \\
\hline & & AA & AG & GG & & $\mathbf{A}$ & G & & \\
\hline \multicolumn{10}{|l|}{ Sex } \\
\hline Female & 86 & $34(39.5)$ & $43(50.0)$ & $9(10.5)$ & 0.677 & III (64.5) & $61(35.5)$ & 0.640 & $1.09(0.76-1.58)$ \\
\hline Male & 216 & $75(34.7)$ & $120(55.6)$ & $21(9.7)$ & & $270(65.5)$ & $162(37.5)$ & & \\
\hline \multicolumn{10}{|l|}{ Age } \\
\hline$\leq 60$ years & 170 & $63(37.1)$ & $91(53.5)$ & $16(9.4)$ & 0.895 & $217(63.8)$ & $123(36.2)$ & 0.667 & $1.08(0.77-1.50)$ \\
\hline$>60$ years & 132 & $46(34.8)$ & $72(54.5)$ & $14(10.6)$ & & $164(62.1)$ & $100(37.9)$ & & \\
\hline \multicolumn{10}{|l|}{ Histological type } \\
\hline $\mathrm{ADC}$ & $|, 38|$ & $49(35.5)$ & $75(54.3)$ & $14(10.1)$ & & $173(62.7)$ & $103(37.3)$ & & \\
\hline SCC & 138 & $47(34.1)$ & $77(55.8)$ & $14(10.1)$ & 0.967 & $171(62.0)$ & $105(38.0)$ & 0.861 & $1.03(0.73-1.46)$ \\
\hline Others & 26 & $13(50.0)$ & II (42.3) & $2(7.7)$ & 0.376 & 37 (7I.2) & $15(28.8)$ & 0.364 & $0.68(0.36-1.30)$ \\
\hline \multicolumn{10}{|l|}{ Differentiation } \\
\hline Poor & 204 & $72(35.3)$ & III (54.4) & $21(10.3)$ & 0.898 & $255(62.5)$ & I53 (37.5) & 0.670 & $0.93(0.65-1.32)$ \\
\hline Moderate-well & 98 & $37(37.8)$ & $52(53.1)$ & $9(9.2)$ & & $126(64.3)$ & $70(35.7)$ & & \\
\hline \multicolumn{10}{|l|}{ Tumor size } \\
\hline TI & 34 & $16(47.1)$ & $16(47.1)$ & $2(5.9)$ & & $48(70.6)$ & $20(29.4)$ & & \\
\hline $\mathrm{T} 2$ & 192 & $72(37.5)$ & $101(52.6)$ & $19(9.9)$ & 0.509 & $245(63.8)$ & $139(36.2)$ & 0.280 & $1.36(0.78-2.39)$ \\
\hline $\mathrm{T} 3$ & 51 & $15(29.4)$ & $28(54.9)$ & $8(15.7)$ & 0.161 & $58(56.9)$ & $44(43.1)$ & 0.070 & $\mathrm{I} .82(0.95-3.5 \mathrm{I})$ \\
\hline $\mathrm{T} 4$ & 25 & $6(24.0)$ & $18(72.0)$ & I (4.0) & 0.156 & $30(60.0)$ & $20(40.0)$ & 0.230 & $1.60(0.74-3.45)$ \\
\hline \multicolumn{10}{|l|}{ Lymph node } \\
\hline NO & 157 & $55(35.0)$ & $87(55.4)$ & $15(9.6)$ & & $197(62.7)$ & 117 (37.3) & & \\
\hline NI & 107 & $48(44.9)$ & 51 (47.7) & $8(7.5)$ & 0.270 & 147 (68.7) & $67(31.3)$ & 0.167 & $0.77(0.53-1.12)$ \\
\hline N2 & 38 & $6(15.8)$ & $25(65.8)$ & 7 (I8.4) & $0.042^{\mathrm{a}}$ & $37(48.7)$ & $39(51.3)$ & $0.024^{\mathrm{a}}$ & $1.78(1.08-2.95)$ \\
\hline \multicolumn{10}{|l|}{ Metastasis } \\
\hline MO & 285 & $103(36.1)$ & $156(54.7)$ & $26(9.1)$ & 0.142 & $362(63.5)$ & $208(36.5)$ & $0.37 \mid$ & $1.37(0.68-2.76)$ \\
\hline MI & 17 & $6(35.3)$ & $7(4 \mid .2)$ & $4(23.5)$ & & $19(55.9)$ & $15(44.1)$ & & \\
\hline \multicolumn{10}{|l|}{ Clinical stage } \\
\hline$I+I I$ & 223 & $90(40.4)$ & II 3 (50.7) & $20(9.0)$ & $0.033^{\mathrm{a}}$ & $193(55.8)$ & $153(44.2)$ & 0.986 & $0.99(0.68-1.46)$ \\
\hline III + IV & 79 & $19(24.1)$ & $50(63.3)$ & $10(12.7)$ & & $88(55.7)$ & $70(44.3)$ & & \\
\hline
\end{tabular}

Note: aStatistically significant.

Abbreviations: ADC, adenocarcinoma; SCC, squamous cell carcinoma; OR, odds ratio; Cl, confidence interval.

response to the chemical carcinogens methylcholanthrene and 7,12-dimethylbenz[a]anthracene. ${ }^{37}$ These results verified the notion of CD226 plays a crucial role in immune surveillance of tumor development. ${ }^{34}$ In addition, one recently published study showed that DNAM-1 was expressed by Vg9Vd2 $\mathrm{T}$ cells, and Nectin-like- 5 but not Nectin-2 was involved in DNAM-1-dependent gammadelta T-cell functions. ${ }^{38}$ Another point is that activated NK cell receptors play a role in ${ }^{\gamma \delta} \mathrm{T}$ cell cytotoxicity, and monoclonal antibody-mediated masking experiments have revealed that cytotoxicity and interferon- $\gamma$ production by human ${ }^{\gamma} \mathrm{T}$ cells in response to hepatocellular carcinomas was CD226-dependent. ${ }^{22,38}$ Therefore, CD226 may act as a tumor surveillance receptor in NK cells.

Interestingly, our present study demonstrated that SNP rs763361 of allele T and SNP rs727088 of allele G were associated with NSCLC, and with lymph node invasion and clinical stage cancer. More importantly, we have provided the first useful evidence that the CD226 gene is associated with NSCLC in the Chinese population. CD226 may be used as a predictor for monitoring cancer, and more importantly, a possible immunotherapy target, which may be useful in clinical applications. Further studies with larger sample sizes in populations of different ethnicities are necessary to confirm our findings.

\section{Acknowledgments}

We thank the patients and their families for their cooperation and support. This work was supported by the National Natural Science Foundation of China (grant number 81372504); and the Science and Technology Support Program of the Science and Technology Department of Sichuan Province (grant number 2014SZ0148).

\section{Disclosure}

The authors report no conflicts of interest in this work.

\section{References}

1. Siegel R, Naishadham D, Jemal A. Cancer statistics, 2012. CA Cancer J Clin. 2012;62:10-29.

2. Sandler A, Gray R, Perry MC, et al. Paclitaxel-carboplatin alone or with bevacizumab for non-small-cell lung cancer. N Engl J Med. 2006; 355:2542-2550.

3. Xu Z, Zhang T, Zhuang R, et al. Increased levels of soluble CD226 in sera accompanied by decreased membrane CD226 expression on peripheral blood mononuclear cells from cancer patients. BMC Immunol. 2009;10:34. 
4. Tian F, Li D, Xia H, et al. Isolation of cDNAs encoding gibbon and monkey platelet and T cell activation antigen 1 (PTA1). DNA Seq. 1999; 10:155-161.

5. Shibuya A, Campbell D, Hannum C, et al. DNAM-1, a novel adhesion molecule involved in the cytolytic function of T lymphocytes. Immunity. 1996;4:573-581.

6. Shibuya A, Lanier LL, Phillips JH. Protein kinase C is involved in the regulation of both signaling and adhesion mediated by DNAX accessory molecule-1 receptor. J Immunol. 1998;161:1671-1676.

7. Maiti AK, Kim-Howard X, Viswanathan P, et al. Non-synonymous variant (Gly307Ser) in CD226 is associated with susceptibility to multiple autoimmune diseases. Rheumatology (Oxford). 2010;49:1239-1244.

8. Hafler JP, Maier LM, Cooper JD, et al. CD226 Gly307Ser association with multiple autoimmune diseases. Genes Immun. 2009;10:5-10.

9. Xu Z, Jin B. A novel interface consisting of homologous immunoglobulin superfamily members with multiple functions. Cell Mol Immunol. 2010;7:11-19.

10. Shibuya K, Lanier LL, Phillips JH, et al. Physical and functional association of LFA-1 with DNAM-1 adhesion molecule. Immunity. 1999;11:615-623.

11. Löfgren SE, Delgado-Vega AM, Gallant CJ, et al. A 3'-untranslated region variant is associated with impaired expression of CD226 in T and natural killer T cells and is associated with susceptibility to systemic lupus erythematosus. Arthritis Rheum. 2010;62:3404-3414.

12. Bossini-Castillo L, Simeon CP, Beretta L, et al; Spanish Scleroderma Group. A multicenter study confirms CD226 gene association with systemic sclerosis-related pulmonary fibrosis. Arthritis Res Ther. 2012; $14: R 85$

13. Zhang C, Ding Z, Lv G, Li J, Zhang JF, Zhou P. CD226 rs727088A $>$ G polymorphism increases the susceptibility to gastric cancer in Chinese populations. Gene. 2015;557:92-97.

14. Shi S, Zhou B, Zhang K, Zhang L. Association between two genetic variants of CD226 gene and Cervical Squamous Cell Carcinoma: a case-control study. Gene. 2013;519:159-163.

15. Sobin LH, Wittekind CH. TNM Classification of Malignant Tumours, 6th ed. Hoboken, NJ: John Wiley \& Sons, 2002.

16. El-Sherbiny YM, Meade JL, Holmes TD, et al. The requirement for DNAM-1, NKG2D, and NKp46 in the natural killer cell-mediated killing of myeloma cells. Cancer Res. 2007;67:8444-8449.

17. Castriconi R, Dondero A, Corrias MV, et al. Natural killer cell-mediated killing of freshly isolated neuroblastoma cells: critical role of DNAX accessory molecule-1-poliovirus receptor interaction. Cancer Res. 2004; 64:9180-9184.

18. Verhoeven DH, de Hooge AS, Mooiman EC, et al. NK cells recognize and lyse Ewing sarcoma cells through NKG2D and DNAM-1 receptor dependent pathways. Mol Immunol. 2008;45:3917-3925.

19. Carlsten M, Malmberg KJ, Ljunggren HG. Natural killer cell-mediated lysis of freshly isolated human tumor cells. Int J Cancer. 2009; $124: 757-762$

20. Gilfillan S, Chan CJ, Cella M, et al. DNAM-1 promotes activation of cytotoxic lymphocytes by nonprofessional antigen-presenting cells and tumors. J Exp Med. 2008;205:2965-2973.

21. Trinchieri G. Biology of natural killer cells. Adv Immunol. 1989;47: $187-376$.

Therapeutics and Clinical Risk Management

\section{Publish your work in this journal}

Therapeutics and Clinical Risk Management is an international, peerreviewed journal of clinical therapeutics and risk management, focusing on concise rapid reporting of clinical studies in all therapeutic areas, outcomes, safety, and programs for the effective, safe, and sustained use of medicines. This journal is indexed on PubMed Central, CAS,
22. Chan CJ, Andrews DM, McLaughlin NM, et al. DNAM-1/CD155 interactions promote cytokine and NK cell-mediated suppression of poorly immunogenic melanoma metastases. J Immunol. 2010;184:902-911.

23. Carlsten M, Björkström NK, Norell H, et al. DNAX accessory molecule-1 mediated recognition of freshly isolated ovarian carcinoma by resting natural killer cells. Cancer Res. 2007;67:1317-1325.

24. Tahara-Hanaoka S, Shibuya K, Kai H, et al. Tumor rejection by the poliovirus receptor family ligands of the DNAM-1 (CD226) receptor. Blood. 2006;107:1491-1496.

25. Masson D, Jarry A, Baury B, et al. Overexpression of the CD155 gene in human colorectal carcinoma. Gut. 2001;49:236-240.

26. Fuchs A, Colonna M. The role of NK cell recognition of nectin and nectin-like proteins in tumor immunosurveillance. Semin Cancer Biol. 2006;16:359-366.

27. Bottino C, Castriconi R, Pende D, et al. Identification of PVR (CD155) and Nectin-2 (CD112) as cell surface ligands for the human DNAM-1 (CD226) activating molecule. J Exp Med. 2003;198:557-567.

28. Fuchs A, Cella M, Giurisato E, Shaw AS, Colonna M. Cutting edge: CD96 (tactile) promotes NK cell-target cell adhesion by interacting with the poliovirus receptor (CD155). J Immunol. 2004;172:3994-3998.

29. Kakehi S, Nakahama K, Morita I. Expression and possible role of PVR/CD155/Necl-5 in osteoclastogenesis. Mol Cell Biochem. 2007; 301:209-217.

30. Pende D, Castriconi R, Romagnani P, et al. Expression of the DNAM-1 ligands, Nectin-2 (CD112) and poliovirus receptor (CD155), on dendritic cells: relevance for natural killer-dendritic cell interaction. Blood. 2006;107:2030-2036.

31. Reymond N, Imbert AM, Devilard E, et al. DNAM-1 and PVR regulate monocyte migration through endothelial junctions. $J$ Exp Med. 2004; 199:1331-1341.

32. Sloan KE, Stewart JK, Treloar AF, Matthews RT, Jay DG. CD155/ PVR enhances glioma cell dispersal by regulating adhesion signaling and focal adhesion dynamics. Cancer Res. 2005;65:10930-10937.

33. Baury B, Masson D, McDermott BM Jr, et al. Identification of secreted CD155 isoforms. Biochem Biophys Res Commun. 2003;309: $175-182$.

34. Carlsten M, Norell H, Bryceson YT, et al. Primary human tumor cells expressing CD155 impair tumor targeting by down-regulating DNAM-1 on NK cells. J Immunol. 2009;183:4921-4930.

35. Soriani A, Zingoni A, Cerboni C, et al. ATM-ATR-dependent upregulation of DNAM-1 and NKG2D ligands on multiple myeloma cells by therapeutic agents results in enhanced NK-cell susceptibility and is associated with a senescent phenotype. Blood. 2009;113:3503-3511.

36. Guerra N, Tan YX, Joncker NT, et al. NKG2D-deficient mice are defective in tumor surveillance in models of spontaneous malignancy. Immunity. 2008;28:571-580.

37. Iguchi-Manaka A, Kai H, Yamashita $\mathrm{Y}$, et al. Accelerated tumor growth in mice deficient in DNAM-1 receptor. J Exp Med. 2008;205: 2959-2964.

38. Toutirais O, Cabillic F, Le Friec G, et al. DNAX accessory molecule-1 (CD226) promotes human hepatocellular carcinoma cell lysis by Vgamma9Vdelta2 T cells. Eur J Immunol. 2009;39:1361-1368.
EMBase, Scopus and the Elsevier Bibliographic databases. The manuscript management system is completely online and includes a very quick and fair peer-review system, which is all easy to use. Visit http://www.dovepress.com/testimonials.php to read real quotes from published authors. 